\title{
Identificação de Avibacterium paragallinarum em frangos de corte e poedeiras comerciais no Estado de Pernambuco ${ }^{1}$
}

INDEX TERMS: Avibacterium paragallinarum, infectious coryza, PCR, isolation, poultry.

RESUMO.- As aves da indústria avícola brasileira são suscetíveis a surtos de doenças infecciosas relacionadas a perdas econômicas, principalmente por enfermidades infecciosas causadas por Mycoplasma, Avibacterium paragallinarum e vírus que acometem o trato respiratório. Objetivou-se neste estudo pesquisar o envolvimento de A. paragallinarum em surto de doença respiratória aviária. Foram coletados 18 swabs da região infraorbitária dos seios nasais de aves, sendo seis amostras de frangos de corte com sinais clínicos e 12 de poedeiras com sinais clínicos. As amostras foram cultivadas em meios específicos para o agente e também

\footnotetext{
${ }^{1}$ Recebido em 16 de dezembro 2013.

Aceito para publicação em 2 de abril de 2014

${ }^{2}$ Laboratório de Doenças Infecciosas dos Animais Domésticos, Departamento de Medicina Veterinária, Universidade Federal Rural de Pernambuco (UFRPE), Av. Dom Manoel de Medeiros s/n, Dois Irmãos, Recife, PE 52171900, Brasil. *Autor para correspondência: rinaldo.mota@pq.cnpq.br

${ }^{3}$ Universidade Federal da Paraíba (UFPB), Cidade Universitária, João Pessoa, PB 58051-900, Brasil.

${ }^{4}$ Laboratório de Diagnóstico Animal (LADA), Rua Caratinga, 62, Madalena, Recife, PE 50720-490.
}

testadas com a técnica molecular Reação em Cadeia de Polimerase. Das amostras analisadas no isolamento, 100\% foram negativas. Na PCR, duas $(16,66 \%)$ foram positivas. A detecção de $A$. paragallinarum na PCR em galinhas poedeiras com sinais clínicos respiratótios indica que esta bactéria está associada à etiologia da síndrome respiratória das aves nas granjas no estado de Pernambuco.

TERMOS DE INDEXAÇÃO: Avibacterium paragallinarum, coriza infecciosa, PCR, isolamento, frangos, poedeiras.

\section{INTRODUÇÃO}

A indústria avícola se caracteriza pela contínua agregação de novas tecnologias o que favorece a intensificação da produção de aves, colocando o Brasil como primeiro exportador de carne de frangos do mundo. Contudo, a indústria avícola brasileira é suscetível a surtos de doenças infecciosas relacionadas a perdas econômicas (Droual et al. 1990).

O impacto econômico causado pelas enfermidades das aves domésticas advém principalmente de doenças infecciosas causadas por Mycoplasma sp., Avibacterium para- 
gallinarum e vírus que acometem o trato respiratório (Mouahid et al. 1989). Dentre estas se destaca a coriza infecciosa (CI) que é uma doença respiratória aguda, sub-aguda ou crônica, que acomete o trato respiratório superior de galinhas, causada pela bactéria Avibacterium paragallinarum (Droual et al. 1990, Yamamoto 1991).

A CI ocorre principalmente em granjas que possuem aves de múltiplas idades sendo influenciada por fatores ambientais como o clima, a superpopulação, a virulência da bactéria e a existência de infecções concorrentes que complicam a infecção (Sandoval et al. 1994). Essa doença desencadeia prejuízos econômicos, advindos da diminuição do desempenho do lote e uma redução acentuada (10$40 \%$ ) na produção de ovos (Blackall \& Matsumoto 2003).

0 método tradicional definitivo para o diagnóstico de CI requer o isolamento da bactéria suspeita e em seguida uma caracterização bioquímica para confirmar a identidade do isolado (Blackall et al. 1997). 0 diagnóstico pode ser realizado com base nos sinais clínicos, em conjunto com a realização de exames microbiológicos e a reação em cadeia de polimerase (PCR) para a identificação precisa do agente, possibilitando a terapêutica mais adequada do caso e estabelecimento de programas de biosseguridade mais eficientes (Chen et al. 1996, Salmon \& Watts 2000).

O estudo da CI é relevante pelas perdas econômicas provocadas pela doença, devido à importância desta enfermidade nos plantéis avícolas. Desta forma objetivou-se neste estudo identificar A. paragallinarum em amostras dos seios infraorbitais de aves provenientes de granjas com surto de doença respiratória aviária no estado de Pernambuco, utilizando as técnicas microbiológicas e PCR.

\section{MATERIAL E MÉTODOS}

O protocolo experimental deste estudo seguiu os Princípios Éticos na Experimentação Animal, adotados pelo Colégio Brasileiro de Experimentação Animal e foi aprovado pelo Comitê de Ética no Uso de Animais da Universidade Federal Rural de Pernambuco (CEUA-UFRPE), Proc. 23082.001526.

Amostragem. Foram colhidas 18 amostras de conteúdo intranasal de frango de corte e poedeira comercial. Dessas amostras, 12 foram formadas por "pools" constituídos de cinco aves cada (seis "pools" de poedeiras e seis "pools" de frangos de corte), além de seis amostras individuais de poedeiras comerciais. Todos os animais apresentavam sinais clínicos de doença respiratória.

Isolamento. Foi realizada a necropsia das aves no momento da coleta para o processamento, as 12 amostras provenientes do pool foram submetidas então ao isolamento, as demais, as seis coletadas por individuo estavam congeladas o que impossibilitou o processamento. Para o isolamento de Avibacterium paragallinarum foram utilizadas placas de Petri contendo ágar base sangue suplementado com soro de galinha e NAD (denominado TM/SN), incubadas a $37^{\circ} \mathrm{C}$ em atmosfera de $5 \%$ de $\mathrm{CO}_{2}$ de acordo com Blackall et al. (1994).

Extração de DNA. Todas as amostras de conteúdo dos seios infraorbitais foram submetidas à extração de DNA, utilizando o kit comercial Genomic DNA Purification, conforme recomendações do fabricante (Wizard $\AA$ ).

PCR. Para reação de amplificação do DNA foi utilizada técnica descrita por Chen et al. (1996), com modificações, consistindo de primers específicos para A. paragalinarum. A reação de PCR constou de $2,75 \mu \mathrm{L}$ de água ultrapura (Milli-Q) por amostra; 6,25 $\mu \mathrm{L}$ de mix; 0,5 $\mu \mathrm{L}$ de cada "primer" (HP - F1: 5' - TGA GGG TAG TCT TGC ACG CGA AT -3' e HP - R1: 5' - CAA GGT ATC GAT CGT CTC TCT ACT -3') por amostra e 2,5 $\mu \mathrm{L}$ do DNA extraído, obtendo-se um volume final de $12,50 \mu \mathrm{L}$. Como controle positivo utilizou-se a cepa padrão cedida pelo professor Dr. Horácio Raúl Terzolo do Instituto Nacional de Tecnologia Agropecuária da Argentina. Como controle negativo foi utilizada água ultrapura (Milli-Q), em substituição ao DNA. As condições da reação consistiram de 25 ciclos de $94^{\circ} \mathrm{C}$ por $1 \mathrm{~min}$, $65^{\circ} \mathrm{C}$ por 1 min e $72^{\circ} \mathrm{C}$ por $2 \mathrm{~min}$, seguida por um ciclo final de $94^{\circ} \mathrm{C}$ por $1 \mathrm{~min}, 65^{\circ} \mathrm{C}$ por $1 \mathrm{~min} \mathrm{e} 72^{\circ} \mathrm{C}$ por $10 \mathrm{~min}$. Os produtos de PCR foram submetidos à eletroforese em gel de agarose $0,8 \%$ por $30 \mathrm{~min}$ a $80 \mathrm{~V}$ e os fragmentos obtidos foram visualizado sob luz ultra violeta.

\section{RESULTADOS}

Os sinais clínicos observados nas aves doentes foram corrimento nasal leve ou abundante, edema facial e estertores respiratórios e os achados necroscópicos foram aerossaculite, presença de hemorragia e muco na traqueia. Das 12 amostras utilizadas no isolamento, $100 \%$ foram negativas. De seis amostras de frangos com presença de sinais clínicos respiratórios, analisadas na PCR, todas foram negativas na PCR, e, das 12 amostras de poedeiras, duas $(16,66 \%)$ foram positivas nesta técnica, sendo essas duas amostras provenientes de swabs individuais.

\section{DISCUSSÃO}

Avibacterium paragallinarum tem um efeito econômico importante na indústria avícola, mesmo a doença sendo de desenvolvimento limitado (Yamamoto 1991). Narita et al. (1978) registraram o isolamento e identificação de A. paragalinarum no Brasil. Em laboratórios de países em desenvolvimento que geralmente têm um menor nível de recursos e muitos problemas de contaminação, o diagnóstico de CI pela cultura e a caracterização com testes bioquímicos é complicado (Chen et al. 1998).

Algumas aves deste estudo apresentavam sinais clínicos sugestivos de $\mathrm{CI}$, todavia esses sinais não são confirmatórios e as lesões patológicas não são patognomônicas (Byarugaba et al. 2006). Clinicamente, as galinhas com sinais sugestivos de CI, também podem estar acometidas por outras doenças, como por exemplo, Ornithobacterium rhinotracheale, cólera aviária crônica, bouba aviária, síndrome da cabeça inchada e avitaminose (Amonsin et al. 1997, Blackall \& Matsumoto 2003).

Chen et al. (1998) recomendaram que os swabs para isolamento de $A$. paragalinarum sejam transportados em G-PBS ou, simplesmente, armazenados secos e enviados para o laboratório a $4^{\circ} \mathrm{C}$, com o período de uma semana entre o tempo de coleta e o processamento da amostra, não influenciando negativamente nos resultados do teste de PCR, porém negativando em testes de cultura. A superioridade do teste de PCR em relação a cultura tradicional é evidente pelo fato de que para o sucesso na cultura, deve ser armazenado em local seco ou no G-PBS e esfregaços devem ser examinados dentro de no máximo três dias. Sendo assim, a PCR é um teste mais eficiente para detecção de $A$. $p a$ ragallinarum do que o cultivo microbiológico em situações em que dificuldades de transporte são encontradas. Esta situação foi enfrentada neste estudo, onde seis amostras 
foram enviadas ao laboratório congeladas o que impossibilitou a realização do cultivo.

As dificuldades na obtenção das amostras de boa qualidade devido ao transporte inadequado de galinhas vivas ou mortas, ou amostras de tecido resultantes de necropsia sem condições adequadas de realização, são bem conhecidas. Juntamente com o transporte, o isolamento e a identificação dificulta o processo de diagnóstico da CI, mesmo em laboratórios que tenham plena condição de isolar e identificar esses micro-organismos, pois requer o crescimento de culturas puras em meios especifícos (Chen et al. 1996, Byarugaba et al. 2006), podendo levar a resultados falso positivo ou negativo. Testes de diagnóstico baseados na PCR oferecem vantagens consideráveis para bactérias como $A$. paragallinarum que são fastidiosas e de difícil crescimento.

Chen et al. (1996) realizaram a identificação de diferentes cepas de A. paragallinarum, dentre elas, duas cepas brasileiras, empregando técnicas moleculares. Ainda, segundo esses autores, quando o cultivo e a técnica molecular foram utilizados nas amostras de campo, a positividade na PCR foi significativamente maior do que a cultura. 0 melhor desempenho da PCR sobre a cultura para amostras de campo, provavelmente, reflete as dificuldades em obtenção de amostras de campo com qualidade suficiente para garantir o crescimento de $A$. paragallinarum.

A PCR pode ser usada diretamente em swabs de seio infraorbital como feito neste estudo; é mais rápida do que a cultura convencional e identificação, podendo o resultado estar disponível dentro de seis horas, em contraste a métodos convencionais que levam pelo menos 3-5 dias. A PCR para diagnóstico de A. paragallinarum deve ser utilizada como um teste realizado no grupo ou plantel para que se tenha um custo reduzido (Chen et al. 1998).

Os animais positivos neste trabalho são de granjas com histórico de vacinação, porém, apesar do amplo uso de vacinas contra a $\mathrm{CI}$, a doença continua a ser um problema grave na indústria avícola. As aves podem ser vacinadas com até vinte semanas de idade, depois de vinte semanas estas aves não podem ser revacinadas e a proteção conferida pela vacinação diminui com o aumento da idade das aves. A eficácia da vacina é, portanto, um problema, sendo necessárias alternativas para as vacinas disponíveis, como a produção de vacinas vivas (Blackall \& Matsumoto 2003).

Em granjas onde vários grupos etários são concomitantes, pode ocorrer a propagação da doença para grupos etários suscetíveis, normalmente ocorrendo dentro de uma a seis semanas após as aves serem removidas da chocadeira para gaiolas de crescimento (Clark \& Godfre 1961), que são os grupos com maiores chances de ter aves infectadas, pois está há mais tempo na granja e já passaram pelo período de incubação da doença. Fato que pode justificar a positividade em poedeiras comerciais, pois são aves mais antigas no plantel, e podem estar mantendo contato com possíveis portadoras, que têm sido reconhecidas como o principal reservatório da infecção (Blackall et al. 1990).

\section{CONCLUSÕES}

A detecção de Avibacterium paragallinarum na PCR em galinhas poedeiras com sinais clínicos respiratórios indica que esta bactéria está associada à etiologia da síndrome respiratória das aves nas granjas no estado de Pernambuco.

A PCR pode ser utilizada como uma ferramenta de diagnóstico e/ou monitoria da Coriza infecciosa em criação avícola comercial.

\section{REFERÊNCIAS}

Amonsin A., Wellehan J., Li L.L., Vandamme P., Lindeman C., Edman M., Robinson R.A. \& Kapur V. 1997. Molecular epidemiology of Ornithobacterium rhinotracheale. J. Clin. Microbiol. 35(11):2894-2898.

Blackall P.J., Morrow C.J., McInnes A., Eaves L.E. \& Rogers D.G. 1990. Epidemiologic studies on infectious coryza outbreaks in northern New South Wales, Australia, using serotyping, biotyping, and chromosomal DNA restriction endonuclease analysis. Avian Dis. 34(2):267-276.

Blackall P.J., Silva E., Yamaguchi T. \& Iritani Y. 1994. Characterization of isolates of avian haemophili from Brazil. Avian Dis. 38:269-274.

Blackall P.J., Matsumoto K. \& Yamamoto R. 1997. Infectious coryza. p.179190. In: Calnek B.W., Barnes H.J., Beard C.W., McDougald L.R. \& Saif Y.M. (Eds), Diseases of Poultry $10^{\text {th }}$ ed. Iowa State University Press, Ames, IA.

Blackall P.J. \& Matsumoto M. 2003. Infectious coryza, p.691-703. In: Saif M., Barnes H.J., Glisson J.R., Fadly A.M., McDougald L.R. \& Swayne D.E. (Eds), Diseases of Poultry. $11^{\text {th }}$ ed. Iowa State University Press, Ames, IA.

Byarugaba D.K., Minga U.M., Gwakisa P.S., Katunguka E.R., Bisgaard M.S. \& Olse J.E. 2006. Occurrence, isolation and characterisation of Avibacterium paragallinarum from poultry in Uganda. Proc. $11^{\text {th }}$ International Symposium on Veterinary Epidemiology and Economics. Avian Dis. 51(2):534-539.

Chen X., Miflin J.K., Zang P. \& Blackall P.J. 1996. Development and application of DNA probes and PCR tests for Haemophilus paragallinarum. Avian Dis. 40(2):398-407.

Chen X., Chen Q., Zang P., Feng W. \& Blackall P.J. 1998. Evaluation of a PCR test for the detection of Haemophilus paragallinarum in China. Avian Pathol. 27:296-300.

Clark B.S. \& Godfrey J.F. 1961. Studies of an inactivated Haemophilus gallinarum vaccine for immunization of chickens against infectious coryza. Avian Dis. 5:37-47.

Droual R.A.A., Bickford A.A., Charlton B.R., Cooper G.L. \& Channing S.E. 1990. Investigation of problems associated with intramuscular breast injection of oil-adjuvanted killed vaccines in chickens. Avian Dis. 34:473-478.

Mouahid M., Bouzoubaa K. \& Zouagui Z. 1989. Chicken infectious coryza in Morocco: epidemiological study and pathogenicity trials. Actes Inst. Agron. Vét., Marrocos, 9:11-16.

Narita N., Hipólito O. \& Bottino J.A. 1978. Studies on infectious coryza. I. The biochemical and serological characteristics of 17 Haemophilus strains isolated in Brazil. Proc. XVI World Poultry Congress, Rio de Janeiro, Vol.5, p.689-692. (Abstracts)

Salmon S.A. \& Watts J.L. 2000. Minimum inhibitory concentration determination for various antimicrobials against 1570 bacterial isolates from turkey poults. Avian Dis. 44:85-98.

Sandoval V.E., Terzolo H.R. \& Blackall P.J. 1994. Complicated infectious coryza cases in Argentina. Avian Dis. 38:672-678.

Yamamoto R. 1991. Infectious coryza, p.186-195. In: Calnek B.W., Barnes H.J., Beard C.W., Reid W.M. \& Yoder Jr H.W. (Eds), Diseases of Poultry. $9^{\text {th }}$ ed. Iowa State University Press, Ames, IA. 